\title{
THE VULNERABILITY OF BALSAM FIR TO SPRUCE BUDWORM ATTACK IN NORTHWESTERN ONTARIO, WITH SPECIAL REFERENCE TO THE PHYSIOLOGICAL AGE OF THE TREE ${ }^{1}$
}

\author{
By J. R. BLAIS ${ }^{2}$
}

\begin{abstract}
The annual defoliation by spruce budworm and the progressive mortality of balsam fir trees were recorded in nine study plots in northwestern Ontario over a period of 11 years. In addition to general observations on the relationship of tree mortality to defoliation, some information was obtained on the relative vulnerability of the trees with respect to size, physiological age (flowering condition), and vigor (site quality).

\section{INTRODUCTION}

Balsam fir, Abies balsamea (L.) Mill., is the main host-tree of the spruce budworm, Choristoneura fumiferana (Clem.). The insect usually feeds on the current year's foliage and on the staminate flowers when they are present. Occasionally, populations of this insect reach such proportions that the larvae feed to some extent on old foliage (Swaine et al., 1924; Balch et al., 1954). Repeated destruction of the current year's foliage results in the death of the trees.

Studies on the relationship of the spruce budworm to the flowering condition of balsam fir were carried out in the Lac Seul infestation area in northwestern Ontario from 1946 to 1950 . The physiologically mature or flowering balsam fir trees usually harbored higher populations than the immature or non-flowering trees, especially during the early developmental stages of the insect (Blais 1952).

The spruce budworm infestation first began in the Lac Seul region about 1940 , and in each succeeding year encroached upon new territories. With the progress of the infestation tree mortality became widespread. Data obtained over a period of eleven years from several study plots furnished information on the effects of repeated defoliation and on the relative vulnerability of flowering and non-flowering balsam fir trees to the attack.

The characteristics of flowering and non-flowering balsam fir trees were discussed in some detail in a previous publication (Blais 1952), so only the more important features are described here. Flowering trees on the average are larger in diameter, total height and crown length than non-flowering trees, and they have more but shorter shoots per unit length of branch. In northwestern Ontario, typical flowering trees produce flowers almost every year although the degree of production varies from year to year. Non-flowering

\footnotetext{
${ }^{1}$ Contribution No. 457, Forest Biology Division, Science Service, Department of Agriculture Ottawa, Canada. Manuscript received March 11, 1958.

'Forest Biology Laboratory, Quebec, Que. Biographical Reference, Forestry Chronicle, Vol. 33.
} 


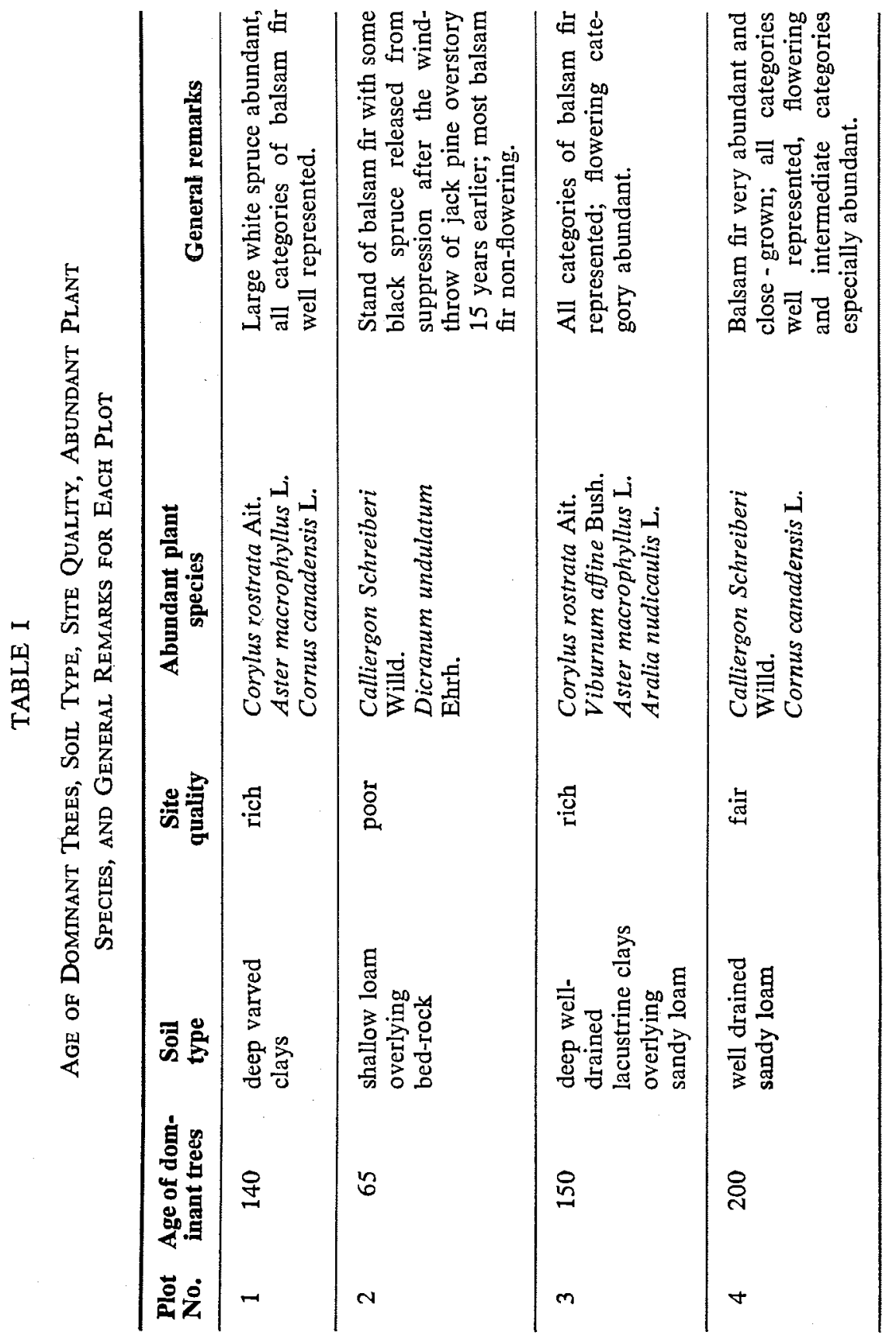


DECEMBER, 1958

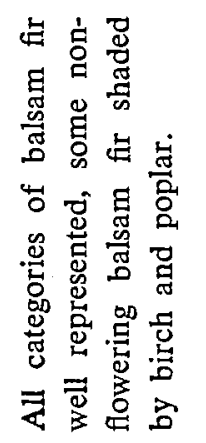

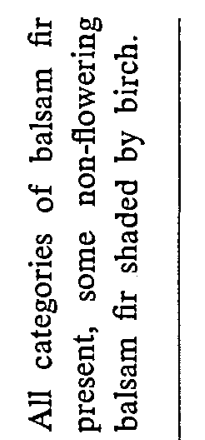

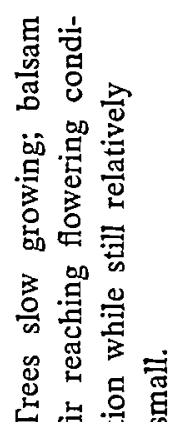

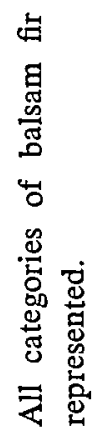

客苍焉主

붕연은

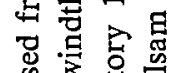

苋 总

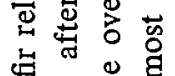

当可品

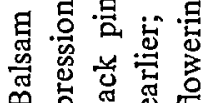

.
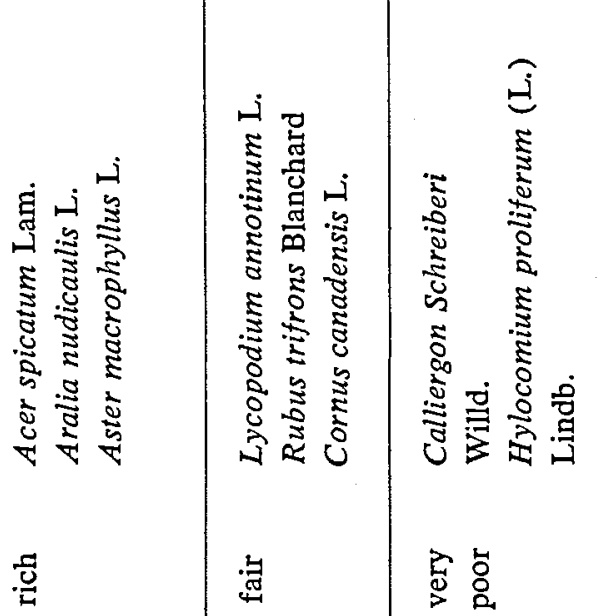

$<$

๑ 回

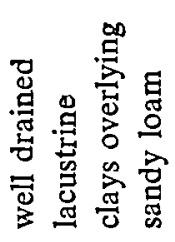

离

客

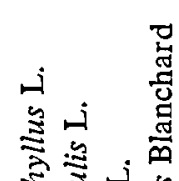

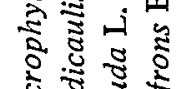

远芯

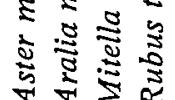

वृ

\begin{tabular}{|c|c|c|c|c|}
\hline & & & & \\
\hline 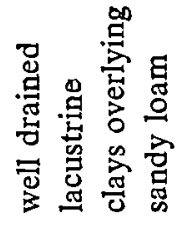 & 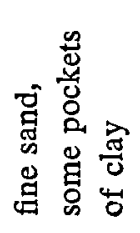 & 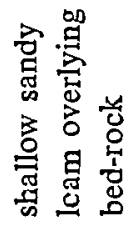 & 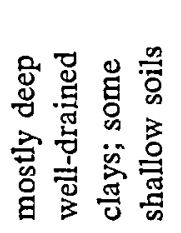 & 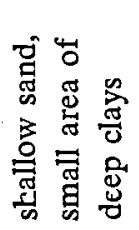 \\
\hline శ్ & ్ㅡㄱ & ָั & $\stackrel{\triangleright}{\infty}$ & $\stackrel{2}{\beth}$ \\
\hline n & 0 & $r$ & $\infty$ & $a$ \\
\hline
\end{tabular}


trees may bear light crops at long intervals. The crown of flowering trees is long and narrowly pointed while in non-flowering trees it is relatively wide in relation to height. Flowering trees are readily recognized by the cup-like scars of the staminate flowers and by the cone spikes that persist on branches of the upper crown for many years. In a mature stand, flowering trees are usually in the dominant and co-dominant crown classes, while non-flowering trees are in the intermediate and suppressed classes. Because of the great tolerance of balsam fir, physiological maturity is influenced not only by age, but to a large extent by exposure to direct sunlight, especially in uneven-aged stands (Morris 1948). The transition from non-flowering to flowering is gradual and usually takes place over several years. All mature balsam fir are flowering trees and in the text the terms are to be taken as synonymous; likewise non-flowering and immature refer to the same tree category.

\section{Methods}

In 1946 and 1947, nine study plots were established in a territory of approximately 120 square miles in the Cedar Lake region of the English River watershed in northwestern Ontario. The stands in which the plots were located

TABLE II

Basal Area of Living Trees in Square Feet per Acre and the Percentage Proportion of each SPecies for Each Plot

\begin{tabular}{lcrrrrrrrr}
\hline Plot & & \multicolumn{7}{c}{ Tree Species1 } \\
\cline { 3 - 10 } number & & Bf & Sw & Sb & Pj & Po & Bw & Pr & Total \\
\hline \multirow{2}{*}{1} & B.A. & 51 & 20 & 0 & 3 & 24 & 2 & 0 & 100 \\
& \% of B.A. & 51 & 20 & 0 & 3 & 24 & 2 & 0 & 100 \\
2 & B.A. & 37 & 2 & 9 & 2 & 1 & 3 & 1 & 55 \\
& \% of B.A. & 68 & 4 & 17 & 3 & 1 & 6 & 1 & 100 \\
3 & B.A. & 48 & 7 & 1 & 0 & 9 & 1 & 0 & 66 \\
& \% of B.A. & 71 & 11 & 2 & 0 & 14 & 2 & 0 & 100 \\
4 & B.A. & 74 & 5 & 17 & 4 & 10 & 5 & 0 & 115 \\
& \% of B.A. & 64 & 5 & 15 & 3 & 9 & 4 & 0 & 100 \\
5 & B.A. & 46 & 14 & 4 & 0 & 8 & 18 & 0 & 90 \\
& $\%$ ofB.A. & 51 & 16 & 4 & 0 & 8 & 21 & 0 & 100 \\
6 & B.A. & 59 & 12 & 3 & 0 & 6 & 35 & 0 & 115 \\
& \% of B.A. & 51 & 11 & 3 & 0 & 5 & 30 & 0 & 100 \\
7 & B.A. & 28 & 7 & 10 & 0 & 4 & 7 & 0 & 56 \\
& \% of B.A. & 50 & 13 & 19 & 0 & 6 & 12 & 0 & 100 \\
8 & B.A. & 39 & 12 & 9 & 4 & 14 & 10 & 0 & 88 \\
& \% of B.A. & 44 & 14 & 10 & 5 & 16 & 11 & 0 & 100 \\
9 & B.A. & 56 & 1 & 1 & 0 & 1 & 8 & 0 & 67 \\
& $\%$ of B.A. & 84 & 2 & 1 & 0 & 1 & 12 & 0 & 100 \\
\hline
\end{tabular}

${ }^{1} \mathrm{Bf}$-Balsam fir, Sw-White spruce, $\mathrm{Sb}-\mathrm{Black}$ spruce, $\mathrm{Pj}-\mathrm{Jack}$ pine, $\mathrm{Po}-$ Trembling aspen, Bw-Paper birch, $\mathrm{Pr}-$ Red pine. 
varied in species composition, age, and site quality as shown in Table 1. Site quality was based on soil conditions and plant species. A detailed tally of all trees over 1 inch d.b.h. was prepared for each plot. The tally was taken on a one-half chain strip through the full length of each plot, which varied between 22 and 44 chains. The basal area of living trees in square feet per acre and the percentage proportion of each species for each plot is shown in Table 2. All balsam fir trees were classified as non-flowering, intermediate flowering, or flowering (Table 3).

In each plot a number of typical flowering and non-flowering trees were selected for defoliation and mortality studies; in addition, trees of the intermediate flowering category were selected in plots 4 to 9 . All selected trees were of merchantable size ( 4 inches d.b.h. and over) and were numbered and described as to diameter at breast height, total height, crown length, crown width, and crown class (Table 3). All plots, except Plot 6, were established in the year of first budworm infestation, this being 1946 for plots 1 to 4, and 1947 for plots 5, 7, 8, and 9. Plot 6 was established in 1947; examination of the foliage indicated that defoliation of the 1946 growth had been approximately 75 per cent, and that there had been no defoliation in 1945 .

Defoliation of the current year's growth for each tree was estimated yearly by the author from 1946 to 1954 , and tree mortality was recorded as it occurred. In 1955 and 1956, E. Smereka made the defoliation estimates and recorded mortality according to established methods. Defoliation of the current year's growth was based on ocular estimates with field glasses, and was classified in the following percentages: $10,25,50,75,90$, and 100 . In the following discussion three defoliation categories with respect to the current year's growth will be referred to: severe (above 75 per cent), moderate (between 25 and 75 per cent), light (below 25 per cent). The current year's growth on balsam fir is readily distinguished since it is lighter in color than the old foliage. This difference in color is most pronounced in the spring and early summer but is still discernible in the fall. Defoliation estimates were made in late July or early August after the end of the feeding period. The 10, 90, and 100 per cent defoliation categories were most common and most easily recognized. Usually, defoliation within the same category of trees within the same plot varied little in any one year. As cumulative defoliation progressed, tops of trees and some terminal twigs died, resulting in reduced shoot production. When this situation prevailed, much greater care had to be exercised in estimating defoliation, since, at first glance, the trees might appear to have lost greater amounts of the current year's foliage than was actually the case. Before making the estimates on the selected trees, one or two trees of each category were felled in the immediate vicinity of the plot and the crowns were closely examined.

Time of defoliation varied from year to year depending on insect numbers and on other factors such as the production of flowers. In some years, the growth was completely destroyed in the bud or at the time of early shoot elongation. In other years, feeding took place when shoot elongation was more advanced and the axes of the shoots were often left intact, only the needles being consumed. The presence or absence of the axes of the current year's shoots was recorded. 


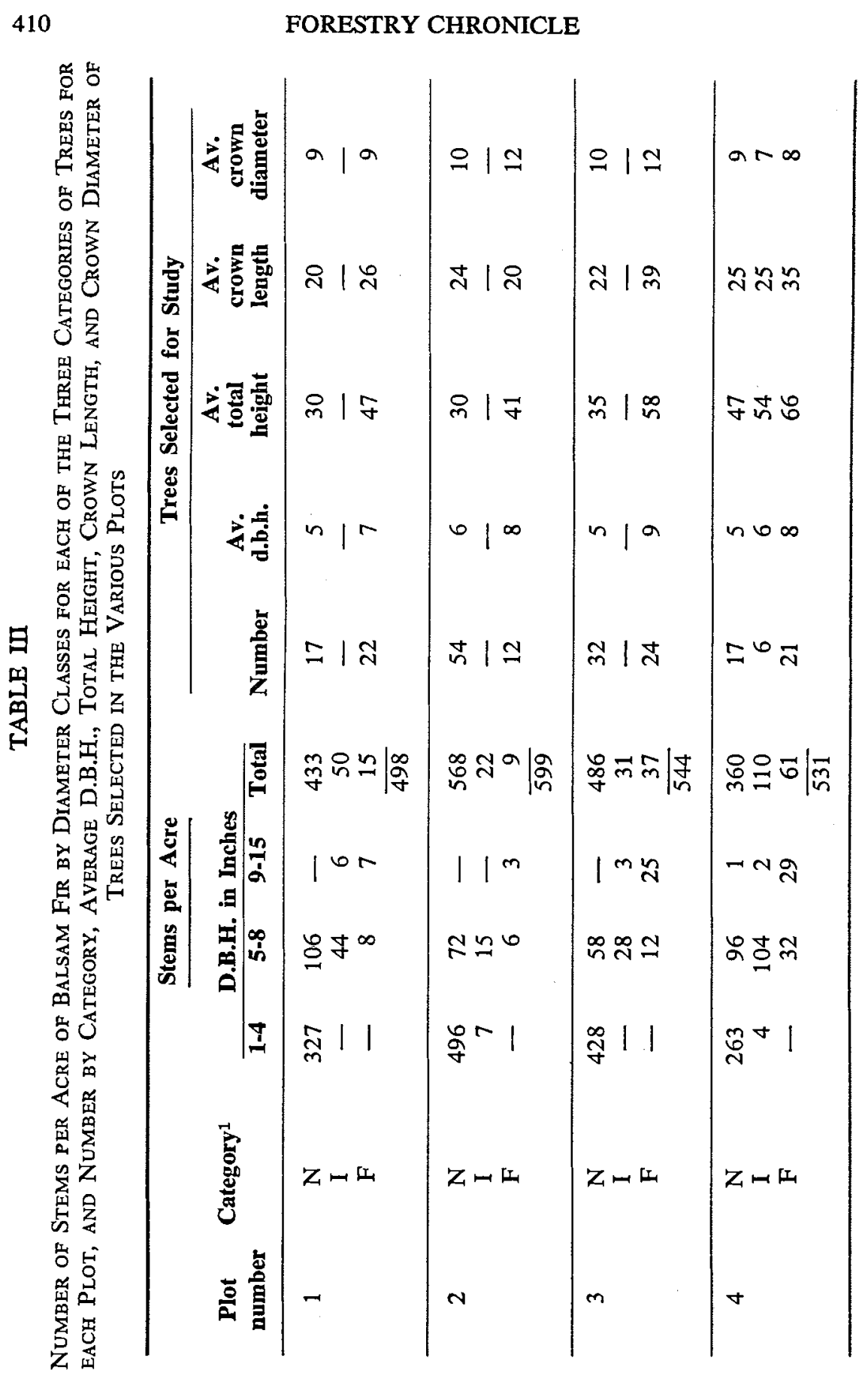




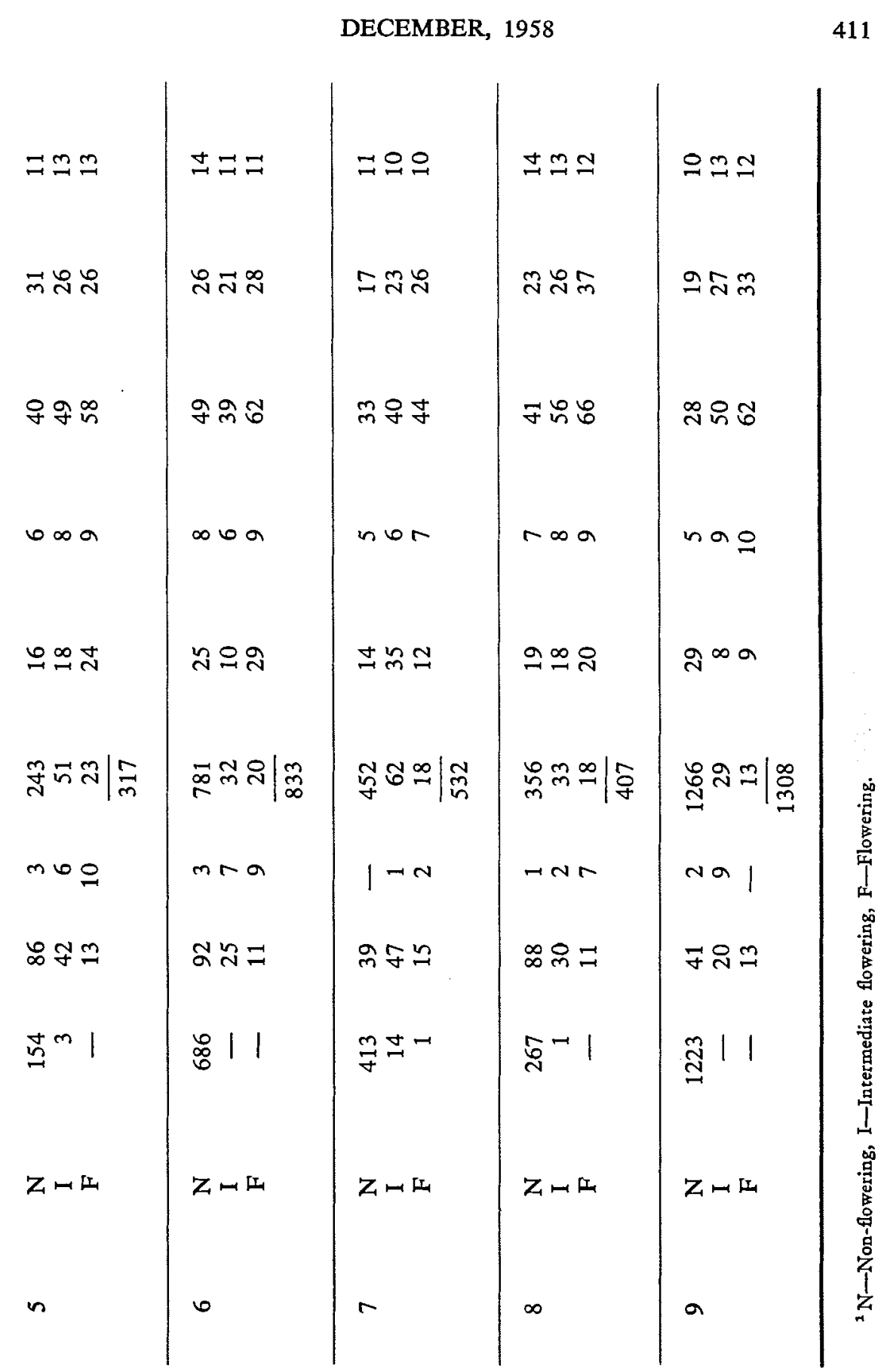




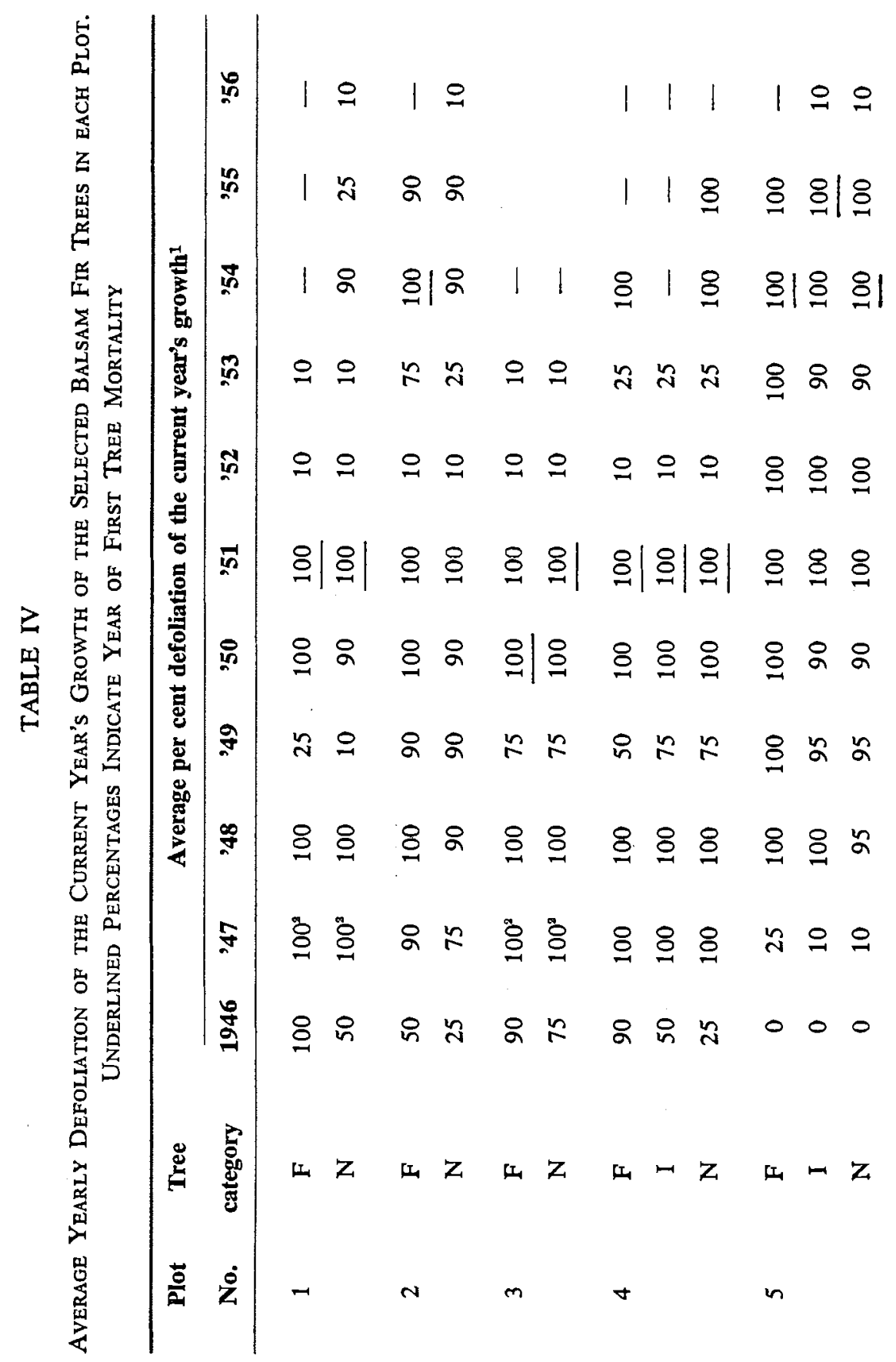




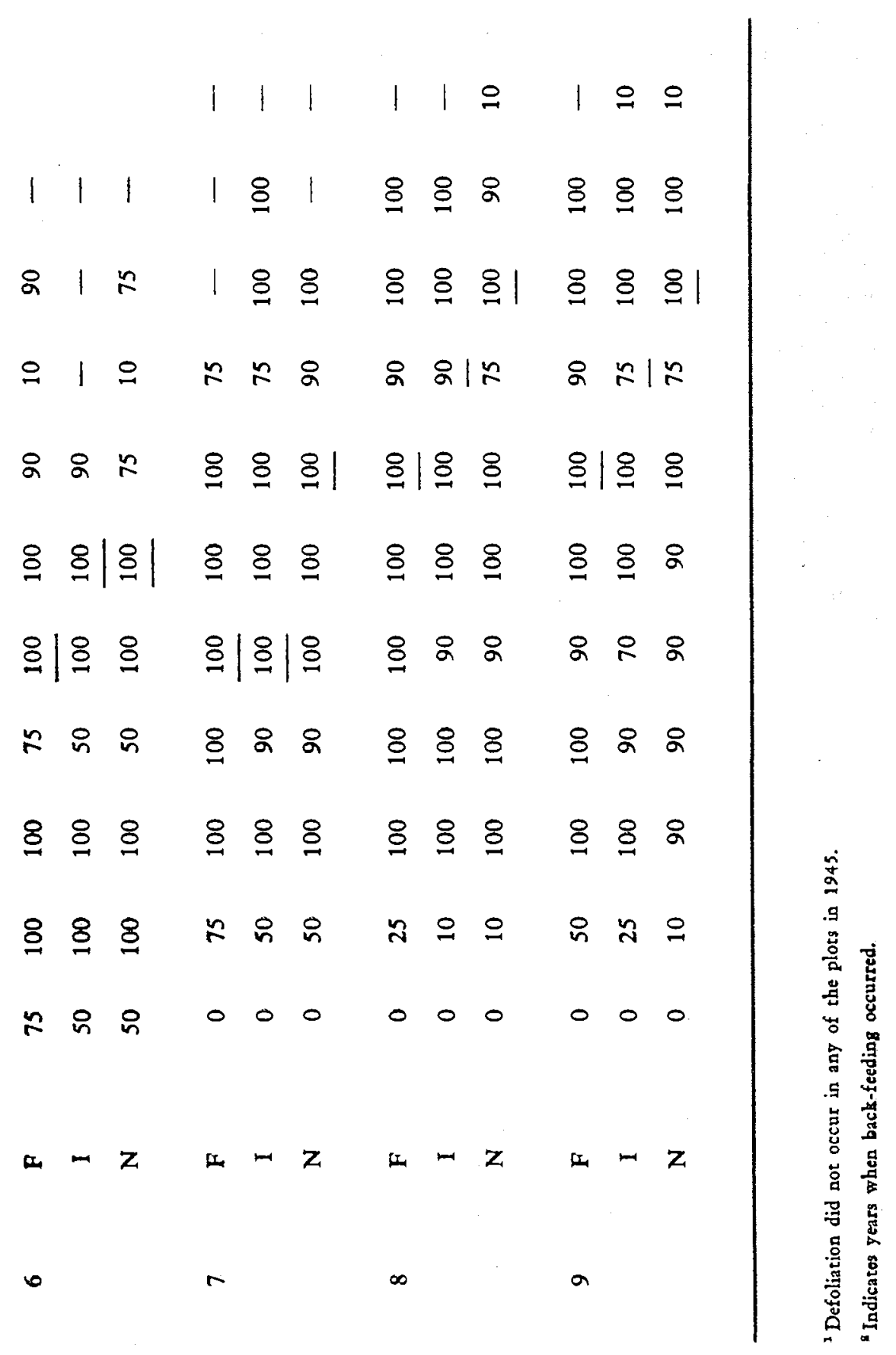


Before a tree was recorded as dead, the cambium was examined and only those exhibiting streaked or brown cambium were included.

\section{History of Defoliation}

\section{RESULTS}

Table 4 gives the yearly defoliation of the current year's growth of balsam fir for each plot. In 1947, in plots 1 and 3, in addition to destroying the current year's growth, the larvae fed to some extent on the old foliage destroying the equivalent of approximately one more year's growth on flowering and one to two more years' growth on non-flowering trees. These were the only instances when feeding on old foliage occurred in any of the plots. The figures in Table 4 refer only to the defoliation of the current year's growth, and not to that of any previous growth. In all plots the transition from no defoliation to severe defoliation was sudden, in some cases there being an intervening year, in others none. Once tree mortality became fairly extensive, defoliation of the surviving trees became more erratic; it was light some years and heavy other years. All categories of balsam fir in all plots experienced repeated heavy defoliation (75 per cent and over) of the current year's growth for five to eight years with the exception of plots 1,4 , and 6 , where severe defoliation was discontinuous because of a temporary reduction in population in 1949. Generally, defoliation of the current year's growth was more severe on flowering than on non-flowering trees, except in those years when all types of trees lost all their new foliage. In only two instances (Plot 4, 1949, and Plot 7, 1953) did non-flowering trees show a higher defoliation of the current year's growth than flowering trees. Intermediate flowering trees usually exhibited an intermediate degree of defoliation. When defoliation of the current year's growth was complete on all categories of trees, axes of the current year's shoots were usually destroyed, otherwise, some or nearly all axes remained.

\section{Progress of Mortality}

The first trees to die in the plots were small suppressed balsam firs less than 3 inches d.b.h. growing under or adjacent to dominant and co-dominant balsam fir and white spruce trees. These suppressed trees were heavily defoliated by larvae dropping from the larger trees. In plots 1 and 3 , the foliage of some of these small trees was completely destroyed by the third year of severe defoliation. However, not all suppressed trees were killed; in fact, it is amongst the smaller trees of this class that survivors are found after a spruce budworm infestation (Blais 1954). Table 4 shows the year of first mortality for tagged trees of each category for each plot. In Plot 7, mortality of balsam fir trees started in the fourth year of severe defoliation, and in Plot 5, in the seventh year. However, first mortality most commonly occurred in the fifth year of severe defoliation. Belyea (1952) records that mortality of mature balsam fir commenced in the fifth year of severe defoliation by the spruce budworm, and that complete or nearly complete mortality of trees was attained eight years after the first year of severe defoliation in the Lake Nipigon infestation in northwestern Ontario.

Trembling aspen and paper birch trees were present in all the study plots and in some (plots 1, 5, 6, and 8) they comprised one quarter or more of the 

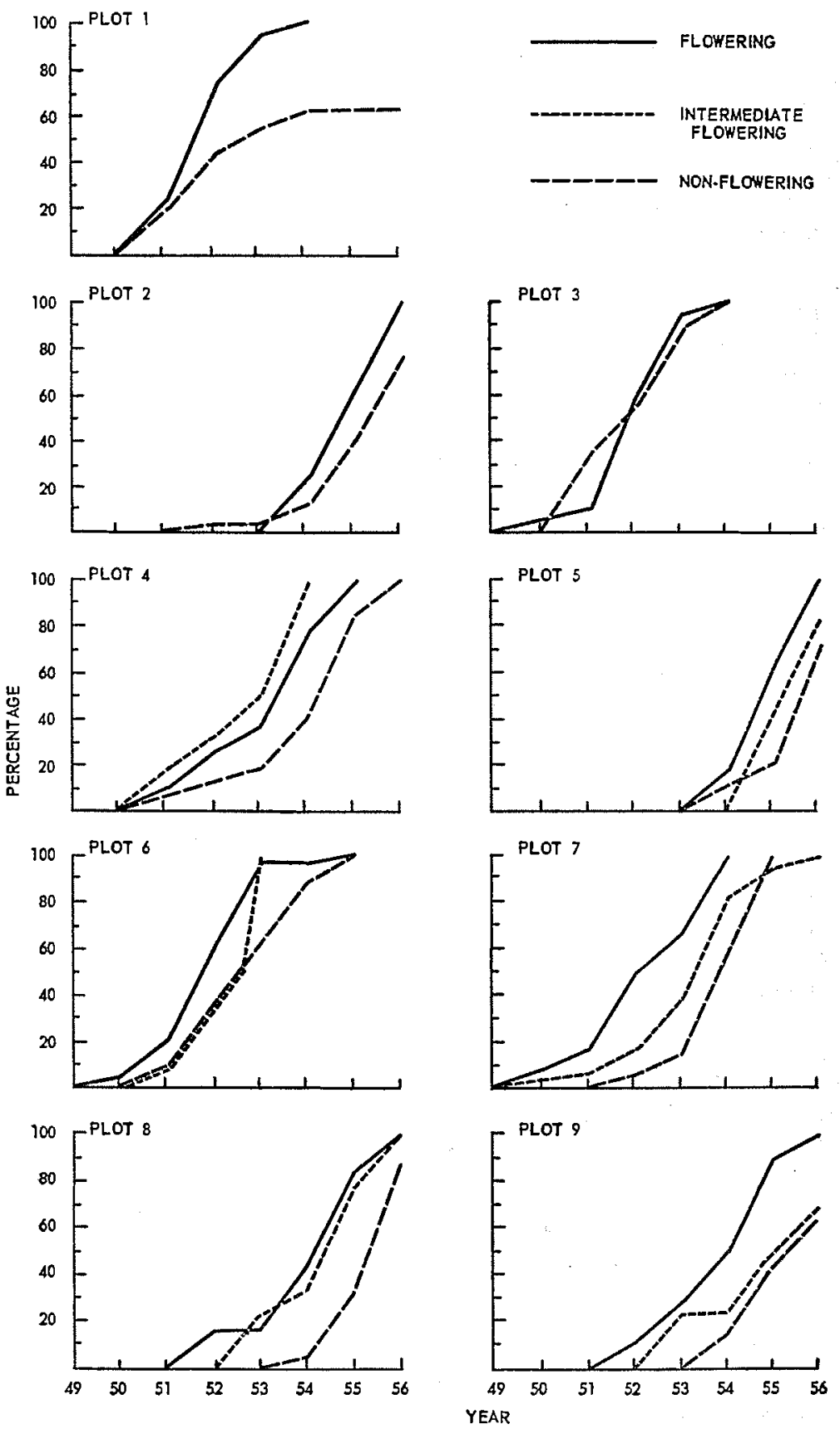

FIGURE 1

Rate of Mortality of the Three Categories of Selected Balsam Fir for Each Plot. 
basal area of the stand (Table 2). As mortality of balsam fir trees progressed in the various plots, it became apparent that trees of all sizes growing in the partial shade of deciduous trees were not as severely defoliated and died later than those growing in the immediate vicinity of other balsam fir or large white spruce trees. Since the spruce budworm is usually attracted to foliage exposed to full sunlight (Wellington and Henson 1947), the partial shade afforded by the deciduous trees provided some protection to the balsam fir growing in their immediate vicinity.

\section{Infuence of Physiological Age on Tree Mortality}

Flowering balsam fir trees tended to die earlier than the intermediate or non-flowering categories. In some plots the first trees to die were exclusively of the flowering category, but in others, some intermediate flowering and nonflowering trees were also amongst the first to die. Figure 1 shows the rate of mortality of flowering and non-flowering trees for each of the nine plots, and of intermediate flowering trees for plots 4 to 9 . In all plots all the selected flowering trees were killed by 1956; in plots 1,2,5, 8, and 9 some non-flowering, and in plots 5 and 9 some intermediate flowering trees were still living in 1956.

The rate of mortality of trees varied between plots and appeared to be dependent on when mortality started in relation to cumulative defoliation. In Plot 7 tree mortality started in the fourth year of defoliation and the rate of mortality was more gradual than in Plot 5 , where mortality started in the eighth year of defoliation (Table 4, and Fig. 1 ).

In all plots the rate of mortality of flowering trees was greater than that of non-flowering trees, except in Plot 3 where the rate of mortality was the same for both categories. The back-feeding that destroyed the equivalent of two years' growth on non-flowering balsam fir in Plot 3 in 1947, might explain why these trees died relatively early. In those plots where records were kept on intermediate flowering trees, these trees generally died at an intermediate rate between the flowering and non-flowering trees. However, in Plot 4 they died earlier, and in Plot 8, at the same rate as the flowering trees.

Although Plot 2 and part of Plot 9 were established in small pockets of immature balsam fir (Table 1), these were not strictly representative of extensive immature or non-flowering stands. In the immediate vicinity of Plot 6, a band of non-flowering trees 10 chains wide and 70 chains long was found. By 1954, much of the timber had been killed in the region where Plot 6 was established, and, in order to obtain a distribution of the dead trees in the nonflowering and the adjoining flowering stand, all balsam fir trees one inch in diameter and over were classified as living or dead on a cruise-line 20 chains long and one-half chain wide. The cruise-line extended for $10 \mathrm{chains}$ through the band of non-flowering trees and for 5 chains on either side through the stand containing flowering trees. Table 5 gives the number of stems per acre of living and dead balsam fir by diameter class for the non-flowering and the adjoining flowering stand. In the non-flowering stand 99 per cent of the trees were still living while in the flowering stand only 20 per cent were living. The distribution of mortality in the flowering stand was about equal for all diameter 
classes. All categories of balsam fir trees growing in the uneven-aged flowering stand were, therefore, much more vulnerable to spruce budworm defoliation than trees growing in the non-flowering stand.

\section{TABLE V}

Number of Stems per Acre of Living and Dead Balsam Fir by Diameter Classes in a Non-Flowering and an Adjoining Flowering Stand. Plot 6, 1954.

\begin{tabular}{llrrrrrrr}
\hline $\begin{array}{c}\text { Type of } \\
\text { stand }\end{array}$ & $\begin{array}{c}\text { Condition } \\
\text { of trees }\end{array}$ & $\mathbf{1 - 2}$ & $\mathbf{3 - 4}$ & $\mathbf{5 - 6}$ & $\mathbf{7 - 8}$ & $\mathbf{9 - 1 3}$ & Total & Percent \\
\hline \multirow{2}{*}{$\mathrm{N}$} & Living & 526 & 122 & 54 & 4 & 2 & 708 & 99 \\
& Dead & 0 & 4 & 0 & 2 & 0 & 6 & 1 \\
\cline { 2 - 9 } & Total & 526 & 126 & 54 & 6 & 2 & 714 & 100 \\
\hline \multirow{2}{*}{ F } & Living & 74 & 68 & 20 & 8 & 2 & 172 & 20 \\
& Dead & 286 & 240 & 126 & 30 & 18 & 700 & 80 \\
\hline & Total & 360 & 308 & 146 & 38 & 20 & 872 & 100 \\
\hline
\end{tabular}

\section{Influence of Cumulative Defoliation on Mortality}

In order to determine if the mortality of any one category of balsam fir in relation to defoliation varied between plots, use was made of an index of cumulative defoliation. This index was calculated for each year by adding the average yearly defoliation up to and including that year and dividing by 100 . If in any one plot the average defoliation of the current year's growth of one tyee category for six consecutive years was $50,100,100,75,100,90$, then the iüdex of cumulative defoliation for successive years would be $0.5,1.5,2.5,3.2$, $4.2,5.1$. As mortality progressed the number of trees used in calculating the index diminished, since only living trees were considered. The index of cumulative defoliation, and the cumulative per cent mortality were plotted for each tree category for each plot by years, and freehand curves were drawn. The index of cumulative defoliation for any amount of mortality could then be read directly from the graphs. The graphs derived from the data for the intermediate category of balsam fir in Plot 7 are shown in Figure 2; very similar graphs were obtained for other trees in other plots. Usually the index of cumulative defoliation followed a straight line whereas the cumulative per cent mortality was a sigmoid curve.

Table 6 gives the index of cumulative defoliation at the 25, 50, and 75 per cent mortality points for the different categories of balsam fir for each plot. Comparison of the vulnerability of balsam fir to spruce budworm defoliation between plots is complicated by differences in defoliation history. In most plots severe defoliation was continuous before the onset of mortality, but in plots 1 , 
2 , and 4, severe defoliation was interrupted by one year of medium or light defoliation before 50 per cent mortality was reached. Notwithstanding these differences in defoliation history, it is evident that the amount of defoliation required to cause tree mortality varied from plot to plot. For example, 50 per cent mortality of flowering trees was reached at a defoliation index of 8.0 in Plot 5, and at a defoliation index of 5.9 in Plot 7, yet in both plots severe cefoliation was continuous.

In some instances mortality of non-flowering trees occurred after a lesser (plots 1, and 2), and in other cases after a greater amount of cumulative defoliation than flowering trees within the same plots. However, the cumulative amount of defoliation required to kill the three categories of trees within any one plot was generally very similar.

Table 6 also gives the total number of years of defoliation and of severe defoliation preceding 25,50 , and 75 per cent mortality of flowering, intermediate flowering, and non-flowering balsam fir for each plot. The number of years of defoliation and of severe defoliation preceding specific amounts of

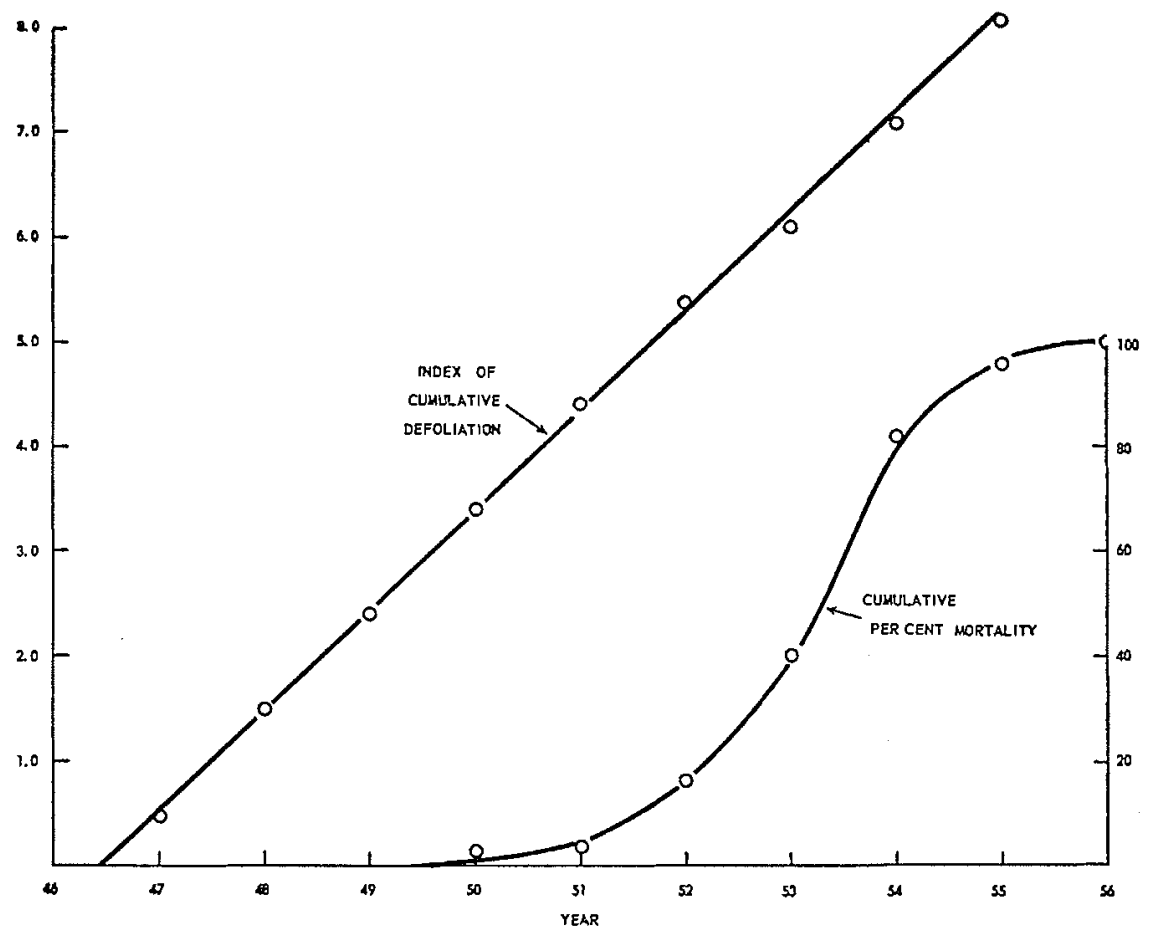

FIGURE 2

Index of Cumulative Defoliation and Cumulative Per Cent Mortality of the Intermediate Flowering Category of Balsam Fir for Plot 7. 
TABLE VI

Index of Cumulative Defoliation at the 25, 50, and 75 Per Cent Mortality Points and Total Number of Years of Defoliation and Severe Defoliation Preceding 25, 50, and 75 Per Cent Mortality of Flowering, InTermediate-Flowering and Non-Flowering Balsam FiR FOR EACH PLOT

\begin{tabular}{|c|c|c|c|c|c|c|c|c|c|c|}
\hline \multirow{2}{*}{$\begin{array}{l}\text { Plot } \\
\text { No. }\end{array}$} & \multirow{2}{*}{$\begin{array}{l}\text { Per cent } \\
\text { mortality }\end{array}$} & \multicolumn{3}{|c|}{$\begin{array}{l}\text { Index of } \\
\text { cum. defol. }\end{array}$} & \multicolumn{3}{|c|}{$\begin{array}{l}\text { No. years } \\
\text { of defol. }\end{array}$} & \multicolumn{3}{|c|}{$\begin{array}{l}\text { No. years of } \\
\text { severe defol. }\end{array}$} \\
\hline & & $\mathbf{F}$ & I & $\mathbf{N}$ & $\mathbf{F}$ & $\mathbf{I}$ & $\mathbf{N}$ & $\mathbf{F}$ & I & $\overrightarrow{\mathbf{N}}$ \\
\hline 1 & $\begin{array}{l}25 \\
50 \\
75\end{array}$ & $\begin{array}{l}5.0^{12} \\
5.3^{12} \\
5.5^{18}\end{array}$ & - & $\begin{array}{c}4.4^{1 \mathrm{a}} \\
4.9^{\mathrm{a}} \\
-\end{array}$ & $\begin{array}{l}6^{a} \\
6^{2} \\
7^{9}\end{array}$ & - & $\begin{array}{c}6^{2} \\
6^{2} \\
-\end{array}$ & $\begin{array}{l}5^{1} \\
5^{3} \\
5^{3}\end{array}$ & E & $\begin{array}{r}4^{1} \\
4^{1} \\
-\end{array}$ \\
\hline 2 & $\begin{array}{l}25 \\
50 \\
75\end{array}$ & $\begin{array}{l}7.5^{1} \\
7.9^{1} \\
8.0^{1}\end{array}$ & - & $\begin{array}{l}6.3^{1} \\
6.6^{1} \\
-\end{array}$ & $\begin{array}{r}9 \\
10 \\
10\end{array}$ & - & $\begin{array}{r}9 \\
10 \\
-\end{array}$ & $\begin{array}{l}7^{1} \\
8^{1} \\
8^{1}\end{array}$ & 二 & $\begin{array}{r}6 \\
7^{1} \\
-\end{array}$ \\
\hline 3 & $\begin{array}{l}25 \\
50 \\
75\end{array}$ & $\begin{array}{l}5.1^{\mathrm{a}} \\
5.8^{\mathrm{a}} \\
5.9^{\mathrm{a}}\end{array}$ & - & $\begin{array}{l}5.0^{2} \\
5.4^{2} \\
5.6^{2}\end{array}$ & $\begin{array}{l}6^{2} \\
7^{8} \\
8^{2}\end{array}$ & - & $\begin{array}{l}6^{2} \\
7^{1} \\
8^{2}\end{array}$ & $\begin{array}{l}6 \\
6 \\
6\end{array}$ & 二 & $\begin{array}{l}6 \\
6 \\
6\end{array}$ \\
\hline 4 & $\begin{array}{l}25 \\
50 \\
75\end{array}$ & $\begin{array}{l}5.8^{1} \\
6.3^{1} \\
6.7^{1}\end{array}$ & $\begin{array}{l}5.2 \\
5.6 \\
5.7\end{array}$ & $\begin{array}{l}5.9^{1} \\
6.5^{1} \\
7.0^{1}\end{array}$ & $\begin{array}{l}7 \\
8 \\
9\end{array}$ & $\begin{array}{l}7 \\
8 \\
9\end{array}$ & $\begin{array}{r}8 \\
9 \\
10\end{array}$ & $\begin{array}{l}5^{1} \\
5^{1} \\
6^{1}\end{array}$ & $\begin{array}{l}5 \\
5 \\
5\end{array}$ & $\begin{array}{l}5 \\
6 \\
7^{3}\end{array}$ \\
\hline 5 & $\begin{array}{l}25 \\
50 \\
75\end{array}$ & $\begin{array}{l}7.5 \\
8.0 \\
8.2\end{array}$ & $\begin{array}{l}7.2 \\
8.0 \\
-\end{array}$ & $\begin{array}{l}7.5 \\
8.4 \\
-\end{array}$ & $\begin{array}{l}8 \\
9 \\
9\end{array}$ & $\begin{array}{r}8 \\
9 \\
10\end{array}$ & $\begin{array}{r}9 \\
10 \\
10\end{array}$ & $\begin{array}{l}7 \\
8 \\
8\end{array}$ & $\begin{array}{l}7 \\
8 \\
8\end{array}$ & $\begin{array}{l}8 \\
8 \\
8\end{array}$ \\
\hline 6 & $\begin{array}{l}25 \\
50 \\
75\end{array}$ & $\begin{array}{l}5.4 \\
5.8 \\
6.3\end{array}$ & $\begin{array}{l}5.4 \\
6.0 \\
-\end{array}$ & $\begin{array}{l}5.1^{1} \\
5.5^{1} \\
6.0^{1}\end{array}$ & $\begin{array}{l}6 \\
7 \\
7\end{array}$ & $\begin{array}{l}6 \\
7 \\
8\end{array}$ & $\begin{array}{l}6 \\
7 \\
8\end{array}$ & $\begin{array}{l}6 \\
7 \\
7\end{array}$ & $\begin{array}{l}4^{1} \\
5^{1} \\
5^{1}\end{array}$ & $\begin{array}{l}4^{3} \\
5^{3} \\
5^{3}\end{array}$ \\
\hline 7 & $\begin{array}{l}25 \\
50 \\
75\end{array}$ & $\begin{array}{l}5.0 \\
5.9 \\
6.6\end{array}$ & $\begin{array}{l}5.8 \\
6.5 \\
7.1\end{array}$ & $\begin{array}{l}6.4 \\
7.2 \\
7.8\end{array}$ & $\begin{array}{l}5 \\
6 \\
7\end{array}$ & $\begin{array}{l}6 \\
7 \\
8\end{array}$ & $\begin{array}{l}7 \\
8 \\
8\end{array}$ & $\begin{array}{l}5 \\
6 \\
7\end{array}$ & $\begin{array}{l}5 \\
6 \\
7\end{array}$ & $\begin{array}{l}6 \\
7 \\
7\end{array}$ \\
\hline 8 & $\begin{array}{l}25 \\
50 \\
75\end{array}$ & $\begin{array}{l}6.6 \\
7.3 \\
7.9\end{array}$ & $\begin{array}{l}6.3 \\
7.4 \\
8.2\end{array}$ & $\begin{array}{l}7.1 \\
7.5 \\
-\end{array}$ & $\begin{array}{l}7 \\
8 \\
9\end{array}$ & $\begin{array}{l}7 \\
9 \\
9\end{array}$ & $\begin{array}{r}8 \\
9 \\
10\end{array}$ & $\begin{array}{l}6 \\
7 \\
8\end{array}$ & $\begin{array}{l}6 \\
8 \\
8\end{array}$ & $\begin{array}{l}7 \\
8 \\
8\end{array}$ \\
\hline 9 & $\begin{array}{l}25 \\
50 \\
75\end{array}$ & $\begin{array}{l}6.2 \\
7.3 \\
8.0\end{array}$ & $\begin{array}{l}6.2 \\
7.5 \\
8.4\end{array}$ & $\begin{array}{l}6.8 \\
7.6 \\
-\end{array}$ & $\begin{array}{l}7 \\
8 \\
9\end{array}$ & $\begin{array}{l}7 \\
9 \\
9\end{array}$ & $\begin{array}{r}8 \\
9 \\
10\end{array}$ & $\begin{array}{l}6 \\
7 \\
8\end{array}$ & $\begin{array}{l}6 \\
8 \\
8\end{array}$ & $\begin{array}{l}7 \\
8 \\
8\end{array}$ \\
\hline
\end{tabular}

'Where years of severe defoliation were discontinuous.

- Trees were subjected to some back-feeding in 1947. 
mortality for any one category of balsam fir varied between different plots by as many as four years. However, once trees started to die the rate of mortality was rapid and the span of years between 25 and 75 per cent mortality was never greater than two. When severe defoliation was interrupted by one or more years of light or moderate defoliation (plots 1,2, 4, and 6), the number of years of severe defoliation required to kill trees was not greater than when severe defoliation was continuous. Furthermore, once defoliation was sufficient to cause some trees to die, mortality continued over a period of years even though defoliation was reduced or ceased. In plots 1 and 3, 1951 was the last year of severe defoliation (Table 4), and only 10 to 30 per cent of the balsam fir trees were dead by that time. In the following three years defoliation was light except for the non-flowering trees in Plot 1 in 1954, yet all the selected balsam fir trees in Plot 3, and all the selected flowering balsam fir trees in Plot 1 were killed in these three years (Fig. 1).

In plots 1, 2, and 6, a given level of mortality of non-flowering trees was effected after a shorter period of severe defoliation than in the flowering trees. Severe defoliation of non-flowering trees in these plots was discontinuous (Table 4), but once initiated, the gradual decline in tree vigor continued notwithstanding one year's respite in defoliation. In all other plots (except Plot 4), severe defoliation was continuous, and either as many or more years of severe defoliation were required to kill non-flowering as flowering trees.

\section{Influence of Site Quality on Mortality}

The site quality of Plot 5 was higher than that of Plot 7 (Table 1). Further evidence of the difference in site quality in plots 5 and 7 was gained from radial growth studies of balsam fir trees in these two plots. The average annual redial growth for the decade preceding defoliation (1936 to 1945) for 50 balsam fir trees of merchantable size in plots 5 and 7 was $2.4 \mathrm{~mm}$. and $1.3 \mathrm{~mm}$. respectively. The difference in the vigor of trees between these two plots probably explains why the trees in Plot 7 offered less resistance to defoliation than those in Plot 5. Although plots 1 and 3 were established on relatively rich sites, the defoliation index associated with 50 per cent mortality of flowering or non-flowering trees in these plots was quite low. This was undoubtedly due to the back-feeding that occurred in these plots in 1947 when the equivalent of two to three years' growth was destroyed in one year.

\section{SUMMARY}

The first trees to succumb to spruce budworm defoliation in nine study plots in the Lac Seul infestation in northwestern Ontario were small suppressed balsam fir (less than 3 inches d.b.h.) growing under mature balsam fir and white spruce. Mortality of this advance growth was initiated by the third year of severe defoliation.

Mortality of balsam fir trees of merchantable size ( 4 inches d.b.h. and over) generally started after five years of severe defoliation, but in some plots mortality started after as few as four years, or after as many as seven years of severe defoliation. Once initiated in a stand, tree mortality was rapid. In all 
the stands studied, two years was the maximum time required for the mortality of merchantable trees to increase from 25 to 75 per cent.

Once cumulative defoliation had been sufficient to cause some trees of merchantable size to die, subsequent mortality was, at least to some degree, independent of subsequent defoliation. Beyond a certain threshold of defoliation, recovery was apparently impossible. For example, in plots 1 and 3, the majority of trees died some years after the last severe defoliation.

When severe defoliation was discontinuous, that is when one year of light or moderate defoliation broke the sequence of years of severe defoliation, the total number of years between initial defoliation and tree death was not any greater than when severe defoliation was continuous. One year's respite in defoliation did not appear to arrest or delay the gradual decline in vigor that ultimately resulted in the death of the trees.

When trees were subjected to the loss of some old foliage in addition to that of the current year's, they died sooner than trees where defoliation was restricted to the cuirent year's growth.

Mortality of flowering trees occurred sooner than that of immature or non-flowering trees. Since the amount of defoliation required to kill both categories of balsam fir trees within a stand was similar, the greater vulnerability of flowering trees was the result of the greater amounts of defoliation to which these trees were subjected. Although the lesser vulnerability of nonflowering trees was apparent when these trees grew intermixed with flowering trees, it was much more apparent in stands composed exclusively of nonflcwering trees. The intermediate category of flowering trees exhibited intermediate characteristics with reference to both defoliation anc vulnerability to budworm attack.

The amount of cumulative defoliation required to cause specific percentages of tree mortality varied considerably between plots, and this could be attributed, at least in part, to site quality. Trees growing on a poor site (Plot 7) offered less resistance to spruce budworm defoliation than those growing on richer sites (Plot 5, Plot 8).

Balsam fir growing in the immediate vicinity of deciduous trees suffered less defoliation and survived longer than those growing in the immediate vicinity of large mature balsam fir and white spruce trees. The partial shade provided by the deciduous trees may have offered some protection against the attack of the spruce budworm, while the dropping of larvae from mature balsam fir and white spruce resulted in the more rapid defoliation and death of overtopped trees.

\section{ACKNOWLEDGEMENT'S}

The author wishes to thank all those who contributed to the execution of the work in the field, especially Mr. E. Smereka who continued the field observations in 1955 and 1956. The Ontario Department of Lands and Forests very kindly provided transportation by aircraft to some of the more inaccessible plots. Grateful appreciation is extended to those members of the Division of Forest Biology who reviewed the manuscript. 


\section{REFERENCES}

BALCH, R. E., F. E. WEBB and R. F. MORRIS. 1954. Results of spraying against spruce budworm in New Brunswick. Can. Dept. Agr. Forest Biol. Div. Bi-mon. Prog. Rept. 10 (1).

BELYEA, R. M. 1952. Death and deterioration of balsam fir weakened by spruce budworm in Ontario, Part II. An assessment of the role of associated insect species in the death of severely weakened trees. J. Forestry 50: 729-738.

BLAIS, J. R. 1952. The relationship of the spruce budworm (Choristonetra fumiferana, Clem.) to the flowering condition of balsam fir (Abies balsamea (L) Mill.) Can. J. Zool. 30: 1-29.

BLAIS, J. R. 1954. The recurrence of spruce budworm infestations in the past century in the Lac Seul area of northwestern Ontario. Ecology 35: 62-71.

MORRIS, R. F. 1948. How old is a balsam trec? For. Chron. 24: 108-110.

SWAINE, J. M., F. C. CRAIGHEAD, and I. W. BAILEY. 1924. Studies on the spruce budworm Cacaecia fumiferana Clem. Can. Dept. Agr., Tech. Bull. 37 (n.s.).

WELLINGTON, W. G. and W. R. HENSON. 1947. Notes on the effects of physical factor on the spruce budworm Choristoncura fumiferana (Clem.) Can. Ent. 79: 168-170; 195. 